\title{
Field in-situ observation on road-embankment integrating soft soil roadbed
}

\author{
Yulin ZOU ${ }^{1, a}$, Zhichao DONG ${ }^{2, b}$, Chuan $\mathrm{HE}^{3, \mathrm{c}}$, Chaofan $\mathrm{YAO}^{4, \mathrm{~d}}$ \\ ${ }^{1,3,4} \mathrm{MOE}$ Key Laboratory of Transportation Tunnel Engineering, Southwest Jiaotong University, \\ Chengdu, 610031, China \\ ${ }^{2}$ Changjiang Institute of Survey, Planning, Design and Research, Wuhan 430010, China \\ azouyulin_617@163.com, b568759976@qq.com, cchuanhe21@home.swjtu.edu.cn, \\ d313842540@qq.com,
}

Keywords: plastic drainage slab, road-embankment integrating, soft soil roadbed, in-situ observation

\begin{abstract}
In the engineering background of a new road-embankment integrating Binjiang Avenue in a city adjacent The Yangtze River, soft soil Roadbed is treated by drainage consolidation method. In-situ observation on test section, which including settlement plate to monitor vertical settlement and inclinometer tube to monitor horizontal settlement, shows that monitoring warning line determined by design is reasonable, and it has certain safety margin. Filling rate has great influence on settlement and lateral displacement rate, and lateral displacement is mainly appeared in mucky clay layer. There exists certain settlement and lateral displacement difference between old embankment and new Roadbed, which would not influence flood control function of embankment. Then monitoring method keeping construction of new Roadbed safe is put forward.
\end{abstract}

\section{Introduction}

Large settlement and settlement difference are appeared during and after construction, and the settlement time is long, due to high compressibility and lower in permeability of soft soil Roadbed [1]. Misconduct would bring foundation instable and brings undue or uneven settlement of road, which would influence construction quality of new road and investment scale. Particularly, high-grade highway with expensive pavement cost and high technology standard has strict acquirement on stability of Roadbed. Thus, treatment on Roadbed, especially deep and soft Roadbed, plays an important role.

\section{Engineering situation}

One city is adjacent to The Yangtze River, where would build an urban secondary road with functions of leisure landscape and flood control. The designed speed is $40 \mathrm{~km} / \mathrm{h}$ with a total length of $20.5 \mathrm{~km}$, and road-embankment integrating is used. The width of embankment top is $40 \mathrm{~m}$. Selecting fill Roadbed and using surcharge preloading with plastic drainage slab to treat deep and soft Roadbed. The main engineering difficult is uneven settlement between new and old embankment and vertical and lateral displacement of old embankment influenced by high fill slope.

\section{Engineering geologic conditions}

According to geologic survey report, the geologic condition along the road is poor within fill compress layer of embankment and soft soil, which is mainly mucky silt clay, is widely distributed. The soft soil contains 2 layers, which are poor engineering geology. The first layer is surface layer of fishpond and ditch with a thickness of $0.5 \sim 2.0 \mathrm{~m}$. The second layer is mucky silt clay-mucky clay with a thickness of 5 21m, as shown in fig.1. Soft soil layer has characteristics of fluidity, heterogeneity and high compressibility, and easy to be dilution shape and easily cause shear deformation and difference in settlement, which is the main poor Roadbed layer causing settlement and instability of high embankment.

\section{Treatment of deep and soft Roadbed}

Generally speaking, there are two ways to treat deep and soft Roadbed [2]. One is drainage consolidation method. The other is reinforcing soil pile method. Drainage consolidation method is 
chosen in this engineering, based on field geologic conditions and similar engineering experience at home and abroad. Selecting standard B-type plastic slab with width of $100 \mathrm{~mm}$ and thickness of $4 \mathrm{~mm}$, and the distance of drainage slab is $1.0 \sim 1.2 \mathrm{~m}$ with a layout of equilateral triangle, which is illustrated in fig.2. In case water flowed in sand layer from The Yangtze River inflows into embankment through plastic drainage slab to form piping and destroy embankment, the drainage must penetrate mucky silt clay.

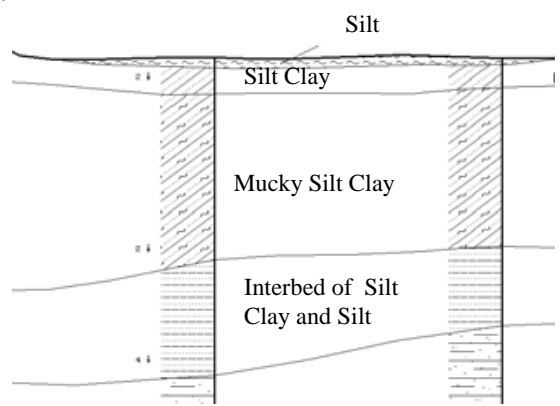

Fig.1 Typical geological section

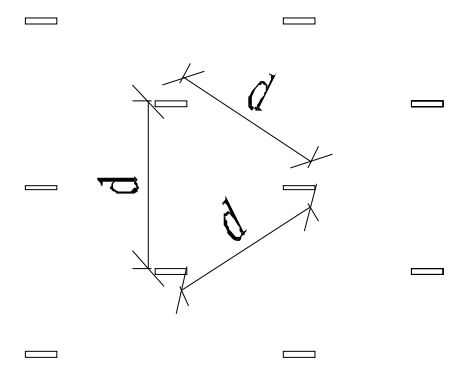

Fig.2 Layout plane of plastic drainage slab

\section{Field test scheme}

\section{Observation point arrangement}

In order to guide construction better and verify feasibility of design scheme(plastic drainage slab + pre-pressure), selecting road sections for $500 \mathrm{~m}$ with high fill as test section. Based on field in-situ monitoring of test section, rationality of various technical parameters in design and influence on old embankment and so on are verified.

The monitoring items of test section mainly include settlement of surface (settlement plate) and horizontal displacement of underground soil mass stratifications. Setting sections in about every two hundred meters in engineering monitoring, this is illustrated in fig.3. A tropical monitoring section is selected as analysis object in this paper.

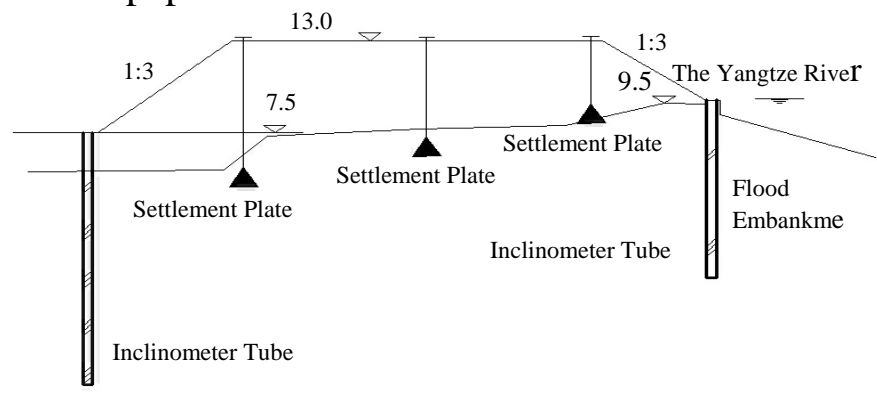

Fig.3 Layout profile of each monitoring instrument

\section{Methods and requirements of instrument layout}

1) Settlement: three settlement plates are arranged in embankments, which are located in center of Roadbed, in inside slope of embankment, in road shoulder away from the embankment. Arranging it under the basement compacted by silt if the basement is silt.

2) Inclinometer: inclinometers should be arranged on each side of road shoulder, which need to penetrate mucky silt clay.

\section{Control requirements of monitoring}

1) Settlement and stability monitoring should be conducted simultaneously during construction, which should be monitored after each layer is filled. And monitoring should be conducted every 3 days if interval between two filling time is long.

2) Settlement should be less than $10 \mathrm{~mm} / \mathrm{d}$ and horizontal displacement should be less than $5 \mathrm{~mm} / \mathrm{d}$ after loading.

\section{Results analysis of field in-situ observation}

\section{Monitoring results analysis of settlement plate}


Settlement of settlement plate develops fast during loading and it slows and develops gently after loading, which is shown in fig.4. Comparatively speaking, settlement in center of Roadbed is larger than that in road shoulders. The largest settlement in Roadbed center is $470.4 \mathrm{~mm}$, while that in road shoulders is $450.8 \mathrm{~mm}$ and $74.7 \mathrm{~mm}$ at inside of embankment.

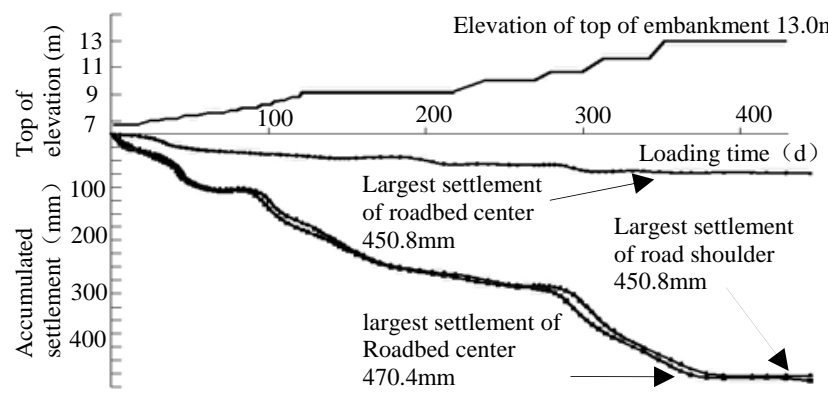

Fig.4 Time-step curves of surface accumulated settlement of monitoring section

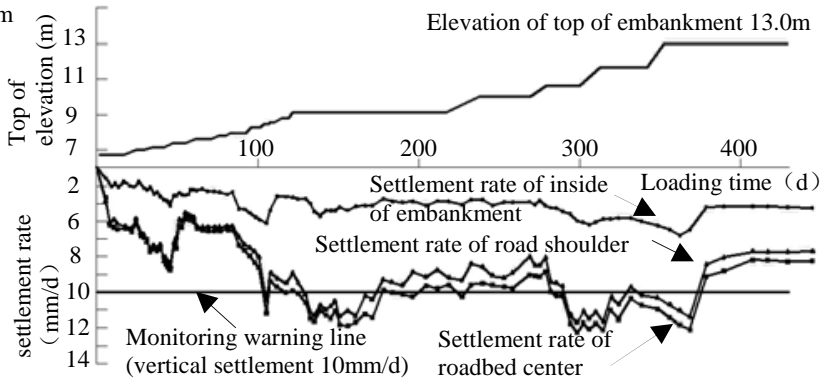

Fig.5 Time-step curves of surface settlement rate of monitoring section

From fig.5 it could be learned that settlement curve is steep when fill height curve is steep, which shows the sensitivity of loading rate influenced by settlement, and settlement rate decreases and converges with time prolonged. It could be found from the time-step curves that the change range of settlement in early period is larger than that in late, which is not only related to fill rate, but also related to high dissipation of pore water due to large porosity and high water content. Embankment settlement rate exceeds monitoring warning line (settlement should less than $10 \mathrm{~mm} / \mathrm{d}$ ) in part of time during loading. At this time, loading rate should be controlled to prevent destabilization.

Generally speaking, fill rate has great influence on Roadbed settlement, and the settlement increases and the rate decreases as the fill finishes and consolidation degree increases [3]. Settlement of settlement slab arranged on one side of old embankment is smaller, which shows the settlement difference between old embankment and new Roadbed. This is due to the consolidation of new Roadbed has not competed, which means there still exists leeway for settlement, and consolidation of old embankment has competed.

\section{Monitoring results analysis of inclinometer}

As shown in fig.6 and fig.7, the largest lateral displacement at road shoulder occurs at 4 meters below the surface, and the largest lateral displacement at embankment occurs at 6 meters below surface. However, according to geologic investigation report, there just exists mucky silty clay layer at elevation between 2 meter and 4 meter, which shows the largest lateral displacement occurs in underground soft soil layer, and the deeper soft soil layer is, the less influence from fill height, the smaller lateral displacement is. The largest lateral displacement at road shoulder is accumulated to $141.8 \mathrm{~mm}$, and that at embankment is accumulated to $52.3 \mathrm{~mm}$.

From fig.8 we could learn that fill rate not only has great influence on Roadbed settlement rate, but also has great influence on lateral displacement. The lateral displacement significantly speeds up during loading, and it significantly slows after loading. Settlement of inclinometer arranged one side of flood embankment is relatively small, which shows that new road would not influence flood control function of old embankment. In other words, it would not bring safety problems. In addition, lateral displacement rate of embankment in part of time exceeds monitoring warning line (lateral displacement should less than $5 \mathrm{~mm} / \mathrm{d}$ ). In this time, loading rate should be controlled strictly to keep Roadbed stable.

Generally speaking, the Roadbed lateral displacement and its rate are positively related to its vertical settlement and its rate [4]. In other words, the higher the fill is and the larger the load is, the larger the settlement and lateral displacement are, which reflects the process of drainage consolidation of Roadbed. 


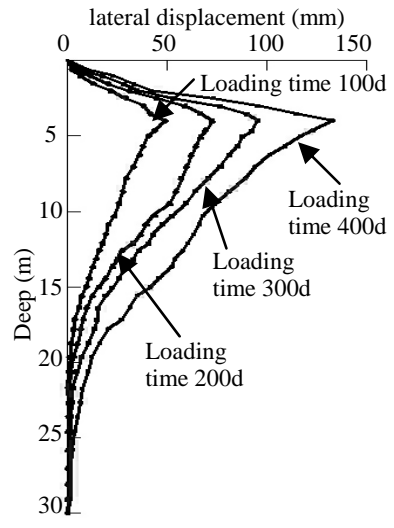

Fig.6 Lateral displacement curves of road shoulder at monitoring section

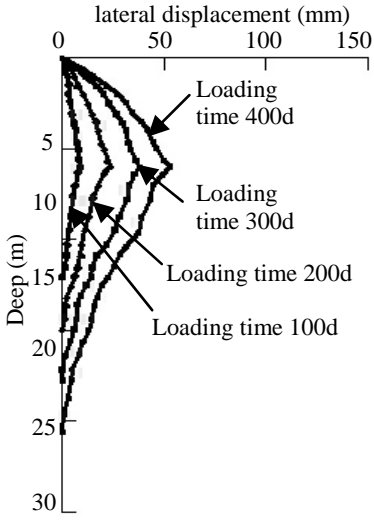

Fig.7 Lateral displacement curves of old embankment at monitoring section

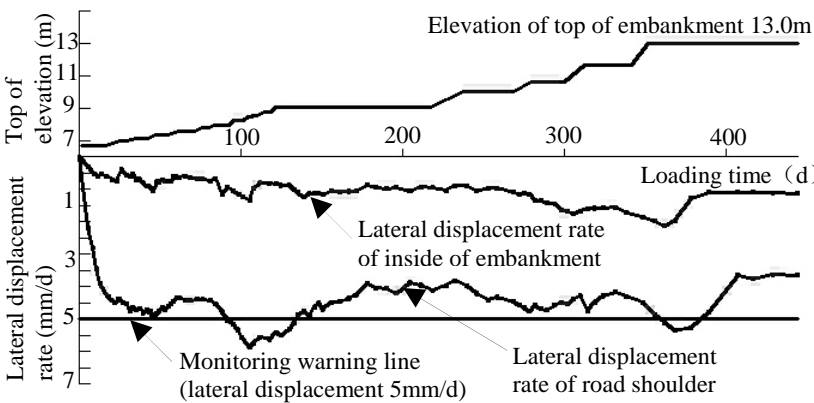

Fig.8 Lateral displacement rate curves of monitoring section

\section{Conclusions}

Some conclusions are made as follows based field in-situ observation of soft soil Roadbed.

1) The loading monitoring warning line established by design, that settlement should be less than $10 \mathrm{~mm} / \mathrm{d}$ and horizontal displacement should be less than $5 \mathrm{~mm} / \mathrm{d}$, is reasonable, and it has certain safety capacity. Loading rate should be controlled strictly when constructing to keep the Roadbed stable.

2) Fill rate has great influence on Roadbed settlement. Settlement is increasing. However its rate is decreasing gradually with the compliment of filling and increasing of consolidation degree of Roadbed.

3) Lateral displacement is mainly occurred in mucky silt clay layer. The lateral displacement and its rate are positively related to Roadbed vertical settlement and its rate. In other words, the higher the fill is and the larger the load is, the larger the settlement and lateral displacement are.

4) There exists certain settlement and lateral displacement difference between old embankment and new Roadbed. This is because consolidation of new Roadbed has not completed, and that of old embankment has completed. Generally speaking, new Roadbed would not influence the flood control function of old embankment, however shear failure and lateral slip failure would easily occurred due to uneven settlement. Thus, loading rate should be controlled strictly and monitoring of settlement and lateral displacement of Roadbed should be strengthened, Paving could be conducted where Roadbed is stable.

\section{References}

[1] Xu Zezhong. Key Technologies of Design and Construction of Highway Soft Soil Roadbed and Embankmenk [M], Beijing: China communications press, 2007

[2] Chen Rui, et al. Treatment Methods for Highway Soft Soil Roadbed[J], Science and Technology of Private Enterprise, 2011, 1

[3] Luo Jianbin, Studies on Construction Control of Highway Soft Soil Subgrad and Embankment Treated by Surcharge Preloading with Plastic Drainage Slab, Xi'an: Master's Thesis of Chang'an University, 2008

[4] Wang Ming. Study on Settlement laws of Soft Soil Roadbed Treated by Surcharge Preloading [D], Changsha: Master's Thesis of Center South University of Forestry and Technology, 2009 